\title{
PV Based Agricultural Pumping System using Boost Inverter Fed Induction Motor
}

\author{
V S Prasadarao K, Nagalinga Chary Kodavatiganti, A V Ravikumar
}

\begin{abstract}
This paper presents a simple, cost-effective scheme for agricultural pumping system. It consists of $P V$ array, canonical switching cell converter (CSCC), Boost inverter, and induction motor. The input power for the boost inverter is obtained from the photovoltaic (PV) based CSCC. The requirement of lower number of components and nonpulsating input current are the superior features of the CSC converter. The conversion of DC voltage obtained from the PV based CSC converter system into high voltage $A C$ using the boost inverter is the main feature of the proposed scheme. Extraction of maximum power from the $P V$ system is ensured in this paper by means of a $P$ \& $O$ MPPT algorithm. Because of a high step up CSC converter and boost inverter, this scheme requires fewer number of $P V$ arrays to power the induction motor for pumping system. Effectiveness of the proposed scheme is verified through MATLAB/SIMULINK environment and necessary results are presented.
\end{abstract}

Keywords: Boost inverter, Canonical Switching Cell Converter (CSCC), Induction Motor, Maximum Power Point Tracking (MPPT), Photo Voltaic (PV) array.

\section{INTRODUCTION}

$\mathbf{R}$ apid growth in power electronic technologies, depletion of fossil fuels and global warming effects driving the society towards the use of renewable energy sources (RES) for different applications [1,2]. Induction motor-based water pumping system using $\mathrm{PV}$ is gaining more attention [3] in the agricultural sector. Generally, this can be carried out by a two-stage conversion system, i.e. DC-to-DC conversion using either boost converter or buck- boost converter and DC to AC conversion using a voltage source inverter (VSI). Although the boost converter provides a high step-up output voltage, but it does not give the smooth starting of the motor [3]. The other buck- boost converters like CUK and SEPIC converters require more number of components making them bulky and inefficient [4]. In addition, VSIs cannot provide high voltage AC output from low voltage DC input. To overcome the above problems, this paper proposes a simple, cost-effective boost inverter fed induction motor drive employing PV based CSCC for water pumping system in the agricultural sector. Advantages of the CSC converter are nonpulsating input current and lower power electronic components [5-7].

Revised Manuscript Received on September 30, 2019.

* Correspondence Author

V S Prasadarao K*, EEE department, Shri Vishnu Engineering College for Women, Bhimavaram, A. P, India. Email: kvsprasad86@gmail.com

Nagalinga Chary Kodavatiganti, EEE department, Lakireddy Bali Reddy College of Engineering, Mylavaram, A. P, India. Email: nagalingachary.k@gmail.com

A V Ravikumar EEE department, Lakireddy Bali Reddy College of Engineering, Mylavaram, A. P, India. Email: ravi0258@gmail.com
Presence of less number of components in the CSC converter makes it more efficient. The most important characteristic of the boost inverter is it is able to

generate high $\mathrm{AC}$ output voltage than its DC input voltage. That means it is not only performing DC to $\mathrm{AC}$ conversion but also provides enhanced AC output voltage, unlike VSI which provides less output voltage from input DC source.

Voltage enhancement feature of CSCC and boost inverters of the proposed scheme reduces the rating of the PV system. Soft starting of the induction motor is ensured by the canonical switching cell converter. Perturbation and observation ( $\mathrm{P} \& \mathrm{O})$ MPPT algorithm is used in this paper to operate the PV array at maximum power point. Finally, the effectiveness of the proposed scheme is verified with the help of MATLAB/SIMULINK software and corresponding results are presented.

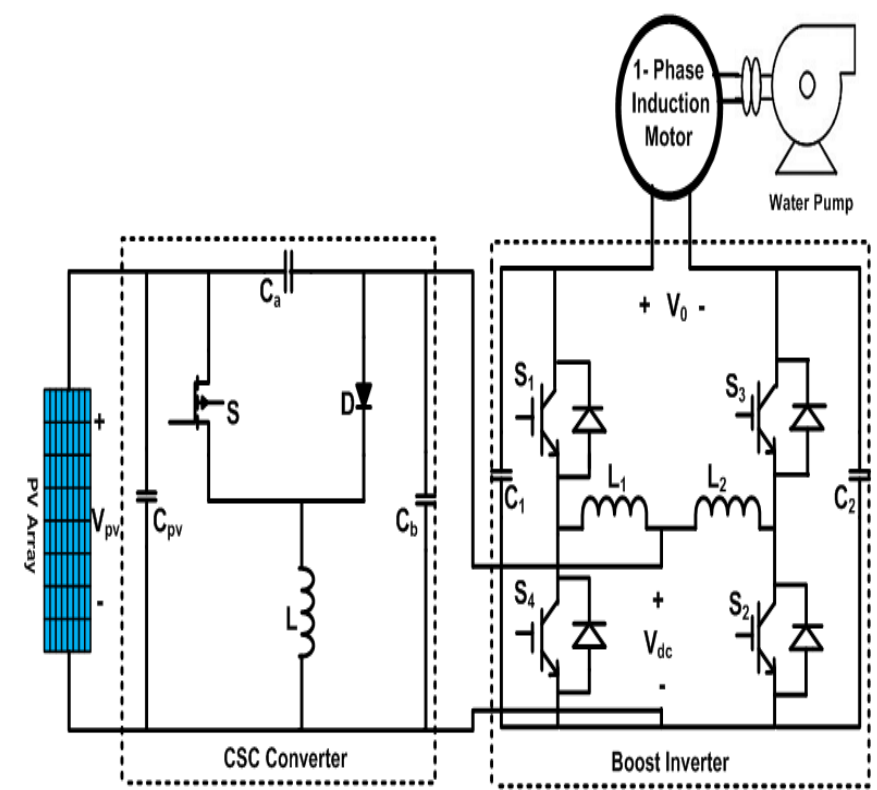

Fig. 1. CSC Converter fed Induction motor for Water pump

\section{CONFIGURATION OF PROPOSED SYSTEM}

The following figure 1 shows the overall structure of the boost inverter fed induction motor drive employing PV based CSC converter for water pumping system. It consists of a PV array, CSC converter, boost inverter, induction motor and a water pump. The power requirement of the water pump is achieved from the PV array via CSCC and boost inverter. The detailed operations of the P\& O based MPPT algorithm, CSCC and boost inverter are explained below. 


\section{A. P \& O Based MPPT Algorithm}

A simple, efficient and commonly used P\& O MPPT algorithm $[8,9]$ is used in this paper to optimize the PV array power $(\mathrm{Pm})$ and also to provide a smooth starting of the induction motor. This algorithm controls the duty cycle (D) of the CSC converter to operate the PV array at maximum power condition. The operation of this algorithm is explained with the help of the P-V curve of the solar array which is shown in figure 2. This algorithm introduces a perturbation to change the operating point of the $\mathrm{P}-\mathrm{V}$ curve according to the following conditions.

(i) If $\frac{d P_{p v}}{d V_{p v}}>0$ (left of the MPPT), then the operating point moves in the forward direction.

(ii) If $\frac{d P_{p v}}{d V_{p v}}<0$ (right of the MPPT, then the operating point moves in the reverse direction.

(iii) Repeat the above process, until $\frac{d P_{p v}}{d V_{p v}}=0$ condition is achieved, which is the required operating point at which the PV array generates the maximum power.

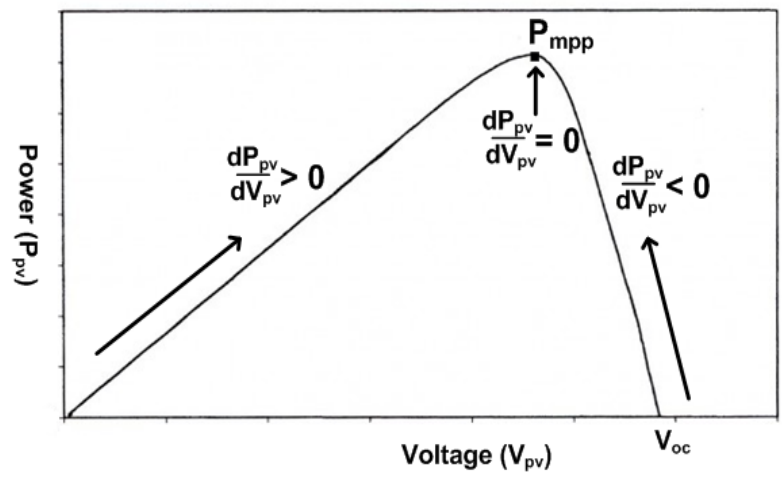

Fig. 2. P-V curve of a solar cell

The following flow chart illustrates the steps involved in the P\& O MPPT algorithm to achieve peak power from the PV array. After the calculating the PV cell voltage V (n), current $I(n)$ and power $P(n)$, calculate the change in the power $(\Delta \mathrm{P})$. If $\Delta \mathrm{P}=0$, then stop the iteration process because, this is the maximum power point tracking condition. If $\Delta \mathrm{P}>0$ and $\Delta \mathrm{V}>0$, then decrease the duty cycle of the dc-dc converter to move the operating point in the forward direction towards MPPT point. If $\Delta \mathrm{P}>0$ and $\Delta \mathrm{V}<0$, then increase the duty cycle of the converter to move the operating point in the forward direction towards MPPT point. If $\Delta \mathrm{P}<0$ and $\Delta \mathrm{V}>0$, then increase the duty cycle to move the operating point in the reverse direction towards MPPT point. If $\Delta \mathrm{P}<0$ and $\Delta \mathrm{V}<0$, then decrease the duty cycle to move the operating point in the reverse direction towards MPPT point.

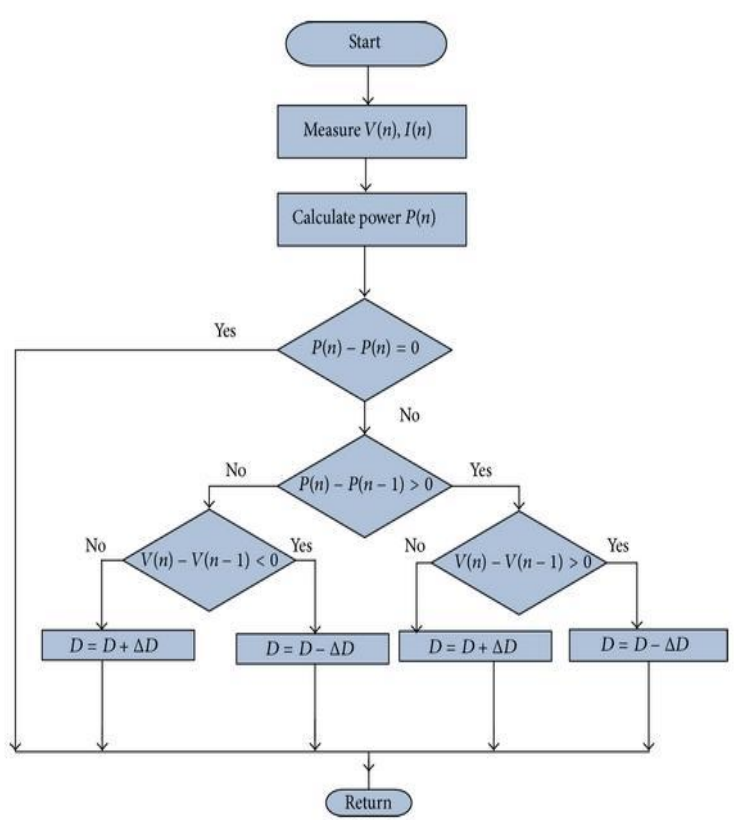

Fig. 3. Flow chart of the P \& O MPPT algorithm

\section{B. Working of CSC Converter}

The circuit arrangement of the CSCC is depicted in figure 4. The principle operation of the CSCC is similar to that of traditional CUK converter. PV array is the input source for the CSC converter. The two operating modes of the CSCC are explained below.

Mode 1: when the switch (S) is closed, the diode (D) becomes reverse bias and the equivalent circuit diagram for this mode is shown in figure 5. In this mode, the energy is transferred from PV and capacitor Ca to the inductor (L). The capacitor $\mathrm{Ca}$ discharges through the inductor and the output capacitor $\mathrm{Cb}$ tries to reduce the voltage across the capacitor Ca.

Mode 2: Due to the opening of switch (S), the diode (D) becomes forward bias in this mode and corresponding equivalent circuit is shown in figure 6 . The energy stored in the inductor $\mathrm{L}$ is transferred to $\mathrm{Ca}$ and $\mathrm{Cb}$.

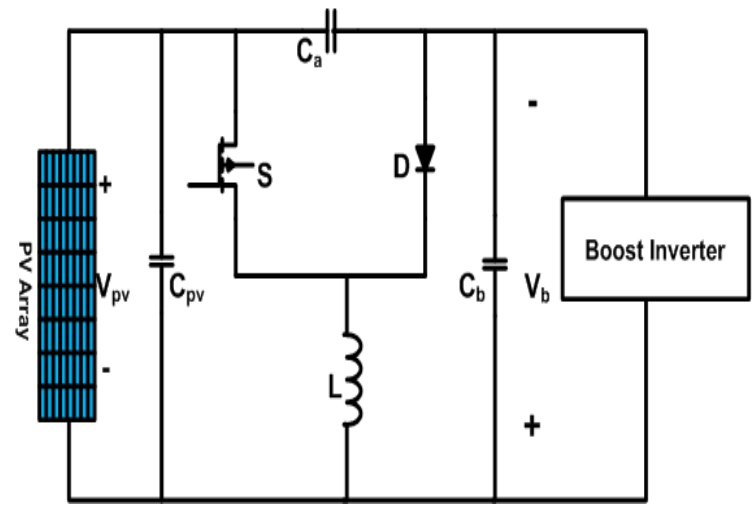

Fig. 4. PV fed Canonical Switching Cell Converter

(CSCC) 


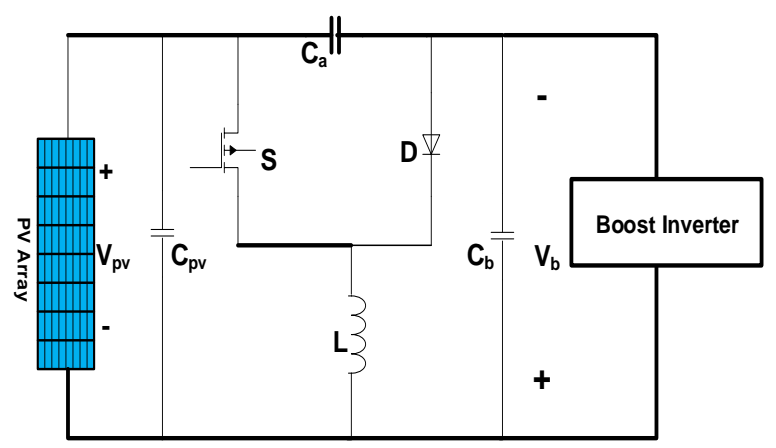

Fig. 5. Mode 1 Circuit diagram

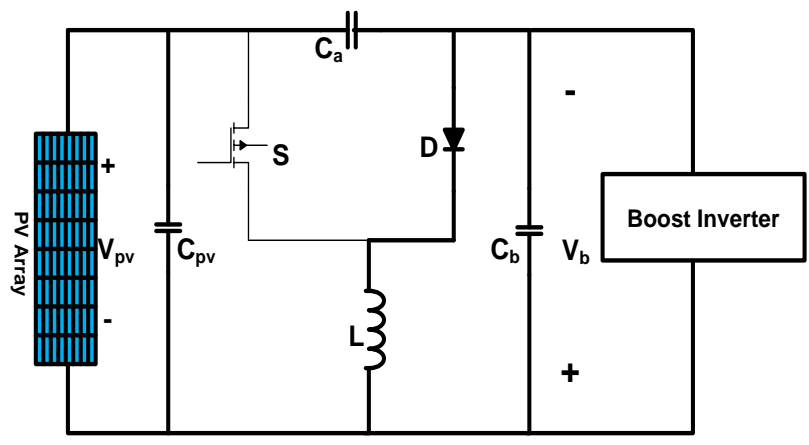

Fig. 6. Mode 2 Circuit diagram

The relation between the average input and the output voltage of the CSC converter is given as,

$$
V_{b}=\frac{D}{1-D} V_{p v}
$$

Where $\mathrm{Vb}=$ average output voltage

$$
\begin{aligned}
& \mathrm{Vpv}=\mathrm{PV} \text { array voltage } \\
& \mathrm{D}=\text { Duty cycle of the CSCC }
\end{aligned}
$$

From above relation, the CSCC provides the required step-up voltage for the boost inverter by controlling the duty cycle. This feature reduces the rating of PV array.

\section{Working of Boost Inverter}

The regulated output of PV fed CSCC is given to the boost inverter to feed the induction motor. The boost inverter [1013] enhances the dc output voltage of the CSCC into AC voltage required for the induction motor. The circuit configuration of the boost inverter is shown in figure 7. It is composed of two converters $\mathrm{A}$ and $\mathrm{B}$, which are operated out of phase with each other. The output voltages of converter A and converter B are given below.

$$
\begin{aligned}
& V_{1}=V_{b}+s \text { in } \omega t \\
& V_{2}=V_{b}-s \text { in } \omega t
\end{aligned}
$$

The resultant output voltage of the boost inverter is given by,

$$
V_{0}=V_{1}-V_{2}=2 V_{m} \sin \omega t
$$

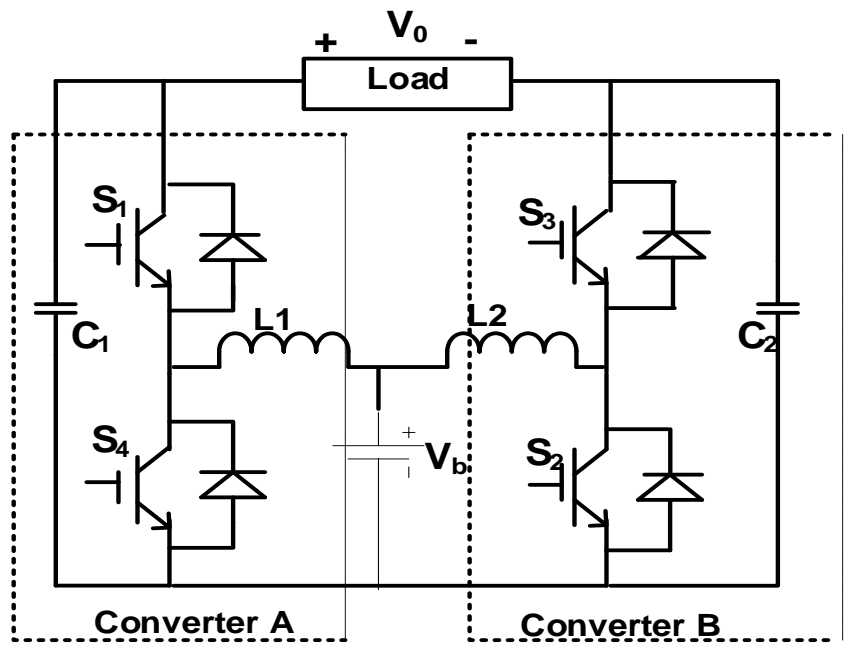

Fig. 7. Circuit configuration of the boost inverter

The relation between input and output voltage of the boost inverter as a function of the duty cycle is obtained as:

$$
V_{0}=\frac{2 D-1}{D(1-D)} V_{b}
$$

From the above relation, the boost inverter is able to produce the higher $\mathrm{AC}$ output voltage, unlike the VSI which produces the lower AC voltage. By controlling the switches, the required $\mathrm{AC}$ output voltage is obtained for the induction motor.

\section{RESULTS AND DISCUSSION}

The feasibility of the presented scheme is verified with the help of MATLAB/SIMULINK software. The data sheet of the solar array considered in the simulation is shown in the table I. The parameters related to the CSC converter, Boost inverter and induction motor are shown in the below table II. The following figures 8 and 9 depicts the I-V and P- V curves of the PV array under standard test condition. The following figures 8 and 9 depicts the I-V and P- V curves of the PV array under standard test condition. From PV curves, it can be found that the PV array generates the maximum power (Pmp) of 200 watts at 26.4 volts.

Table I: Data sheet of the PV Array under $1000 \mathrm{w} / \mathrm{m} 2$, $250^{\circ} \mathrm{C}$

\begin{tabular}{|c|c|c|}
\hline S. NO & Parameter & Value \\
\hline 1 & Maximum Power (Pmp) & 200 Watts \\
\hline 2 & Voltage at maximum power (Vmp) & 26.4 Volts \\
\hline 3 & Current at maximum power (Imp) & $7.58 \mathrm{~A}$ \\
\hline 4 & Open circuit voltage (Voc) & 32.9 Volts \\
\hline 5 & Short circuit current (Isc) & $8.21 \mathrm{~A}$ \\
\hline 6 & Total number of cells in series (Ns) & 54 \\
\hline 7 & Total number of cells in parallel (Np) & 1 \\
\hline
\end{tabular}


Table II: Parameters of the system for simulation

\begin{tabular}{|c|c|c|}
\hline S. NO & Parameter & Value \\
\hline \multicolumn{3}{|c|}{ CSC Converter } \\
\hline 1 & Indictor, $\mathrm{L}$ & $90 \mu \mathrm{H}$ \\
\hline 2 & Intermediate capacitor, $\mathrm{Ca}$ & $0.66 \mu \mathrm{H}$ \\
\hline 3 & Output capacitor, $\mathrm{Cb}$ & $100 \mu \mathrm{H}$ \\
\hline \multicolumn{3}{|c|}{ Boost Inverter } \\
\hline 1 & Inductors, L1, L2 & $10 \mathrm{mH}$ \\
\hline 2 & Capacitors, $\mathrm{C} 1, \mathrm{C} 2$ & $500 \mu \mathrm{F}$ \\
\hline \multicolumn{3}{|c|}{$1-\varphi$ Induction Motor } \\
\hline 1 & Main winding stator resistance, $\mathrm{Rs}$ & $2.02 \Omega$ \\
\hline 2 & Main winding stator inductance, Ls & 7.4mH \\
\hline 3 & Auxiliary winding resistance, $\mathrm{Ra}$ & $7.14 \Omega$ \\
\hline 4 & Auxiliary winding inductance, $\mathrm{La}$ & $8.54 \mathrm{mH}$ \\
\hline 5 & Main winding rotor resistance, $\mathrm{Rr}$ & $4.12 \Omega$ \\
\hline 6 & Main winding rotor inductance, $\mathrm{Lr}$ & $5.6 \mathrm{mH}$ \\
\hline 7 & Rated Speed & 1500RPM \\
\hline 8 & Load torque & $2 \mathrm{~N}-\mathrm{m}$ \\
\hline
\end{tabular}

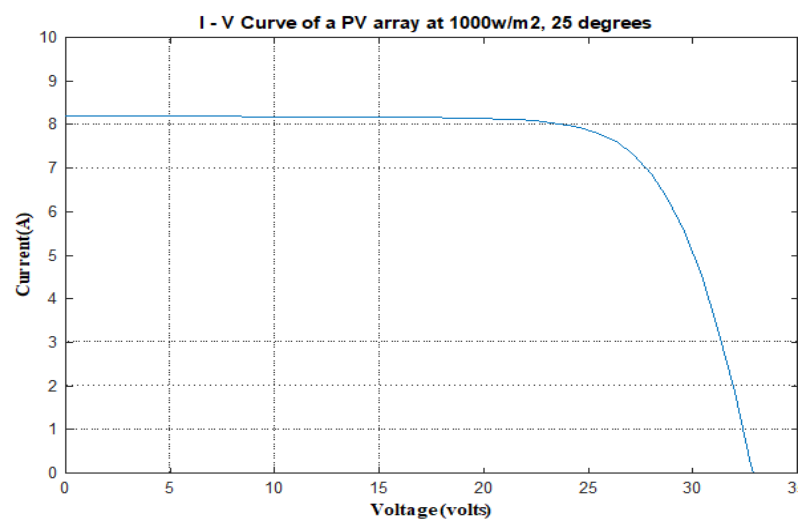

Fig. 8. I - V curve of the PV Array under standard test conditions

Figure 10 shows the ability of P\&O MPPT algorithm to extract maximum power from the PV array considered. It also shows the voltage and currents are also at the maximum power point.

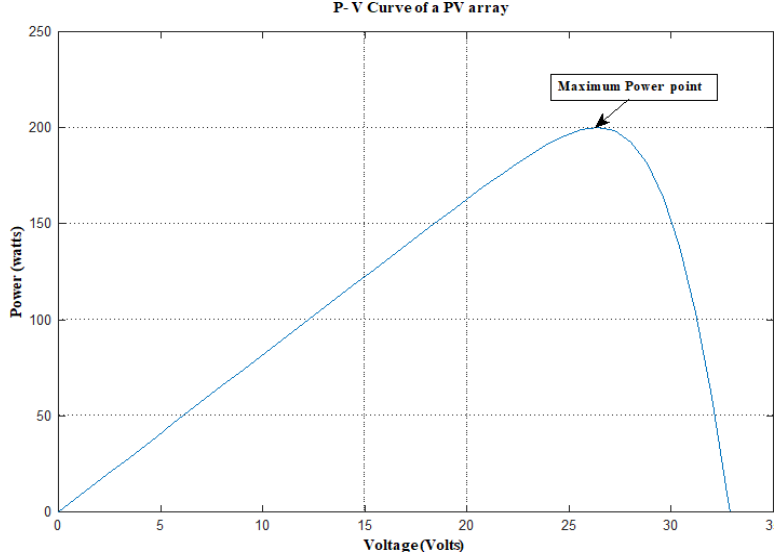

Fig. 9. $P-V$ curve of the PV Array under standard test conditions
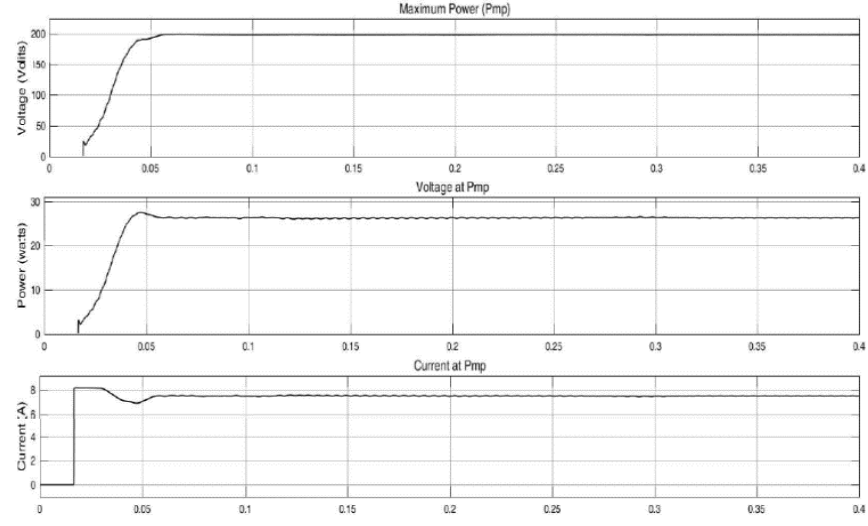

Fig. 10. Maximum power, Voltage and currents at Pmp of the PV array

The voltage obtained from the PV system is low and it is not sufficient to drive the inverter fed induction motor for agricultural pumping system. To enhance the low voltage obtained from the PV array, a CSC is used in this paper. Figure 11 shows the input and output voltages of the CSC converter.

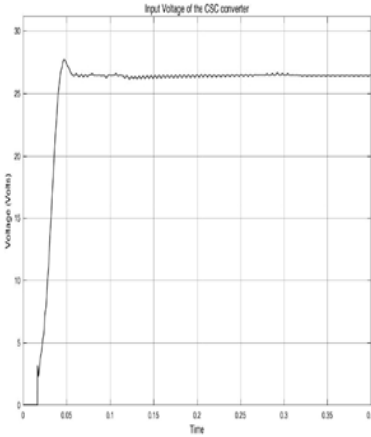

(a)

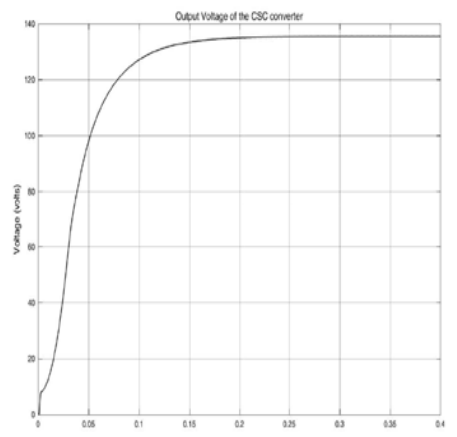

(b)
Fig. 11. (a) Input voltage (b) Output voltage of the CSC converter

From the above figure, the CSC converter enhances the low voltage DC (26 Volts) obtained from the PV into high voltage (135 Volts) required for the inverter fed induction motor. The input to the induction motor is obtained from the boost inverter, which is fed from the CSC converter. The main advantage of the boost inverter is it generates high voltage $\mathrm{AC}$ from the $\mathrm{CSC}$ converter in a single stage which is shown in the below figure.

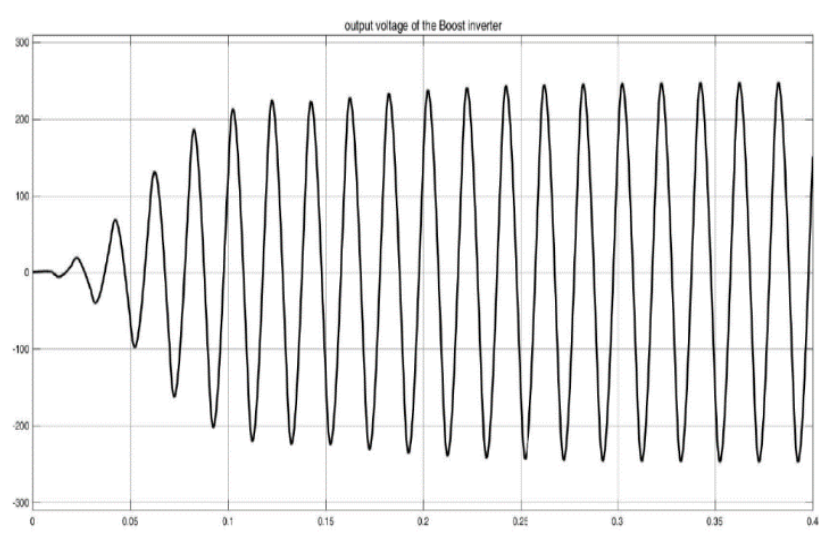

Fig. 12. Output voltage of the Boost inverter 
Finally, the boost inverter is used to drive the induction motor for agricultural pumping system. The corresponding waveforms of the induction motor i.e. speed and torque are shown in the below figure 13 .
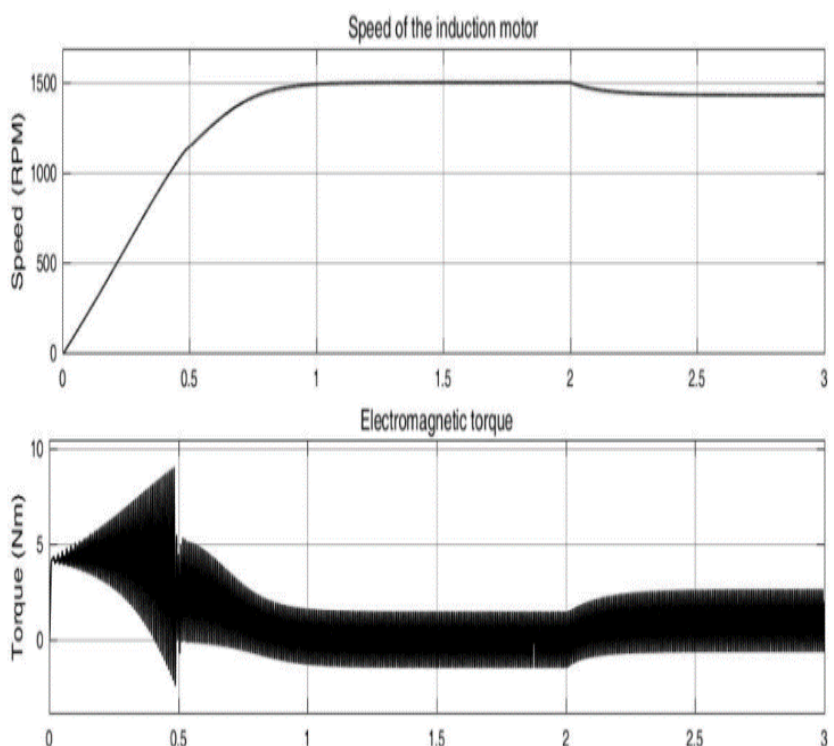

Fig. 13. Speed and torque developed by the induction motor

From the above figure, up to 2 seconds, the speed of the induction motor is at its rated value (1500 RPM) under no load condition. At $\mathrm{t}=2$ seconds, a load of $2 \mathrm{~N}-\mathrm{m}$ is connected to the motor and hence the speed of the motor is reduced to 1400 RPM.

\section{CONCLUSION}

This paper presents the simple and cost-effective drive system for agricultural pumping system. The proposed scheme requires less number of $\mathrm{PV}$ arrays to run the single-phase induction motor. The P \& O MPPT algorithm used in this paper is effectively tracked the maximum power from the PV array. The CSC converter and Boost inverters used in the proposed scheme enhances the low voltage input into high voltage required for the induction motor. Due to the lower components presented in both converters reduces the size and implementation cost of the system.

\section{REFERENCES}

1. Mukhtiar Singh, Vinod Khadkikar, Ambrish Chandraand Rajiv K. Varma, "Grid Interconnection of Renewable Energy Sources at the Distribution Level with Power-Quality Improvement Features", IEEE Trans. Power delivery, Nov. 2010, pp. 307-315.

2. S. D. Gamini Jayasinghe, D. Mahinda Vilathgamuwa, and U. K. Madawala, "Diode-clamped three-level inverter-based 4. battery/ supercapacitor direct integration scheme for renewable energy systems," IEEE Trans. Power Electron., Vol. 26, No. 6, Dec.2011, pp. 3720-3729.

3. Rajan Kumar, and Bhim Singh "BLDC Motor-Driven Solar PV Array-Fed Water Pumping System Employing Zeta Converter," IEEE Trans. Industry Applications., Vol. 52, No. 3, May. 2016, pp. 2315-2322.

4. R. Kumar and B. Singh, "Buck-boost converter fed BLDC motor drive for solar PV array based water pumping," in Proc. IEEE Int. Conf. Power Electron. Drives Energy Syst. (PEDES), Dec. 16-19, 2014, pp. 1-6.

5. B. Williams, "Generation and analysis of canonical switching cell dc to dc converters," IEEE Trans. Ind. Electron., vol. 61, no. 1, Jan. 2014, pp. 329-346.
6. K. Matsui, I. Yamamoto, T. Kishi, M. Hasegawa, H. Mori, and F. Ueda, "A comparison of various buck-boost converters and their application to PFC," in Proc. 28th IEEE-IECON Conf., vol. 1, Nov. 5-8, 2002, pp. $30-36$.

7. Y. Ando, K. Matsui, and M. Hasegawa, "Discussions on various chopper circuits for power factor corrections," in Proc. IEEE Int. Symp. Ind. Electron, 2013, pp. 1-6.

8. Ahmed Saeed Ahmed, Bassem A. Abdullah, Wahied Gharieb and Ali Abdelaal,"MPPT Algorithms: Performance and Evaluation", ," in Proc. 11th ICCES Conf., Dec. 21-22, 2016, pp. 461-467.

9. Ting-Chung Yu, and Yu-Cheng Lin. "A Study on Maximum Power Point Tracking Algorithms for Photovoltaic Systems." Lunghwa University of Science and Technology, 2010, pp. 3-4-5.

10. R. O. Cáceres and I. Barbi, "A boost DC-AC converter: Analysis, design, and experimentation," in Proc. IEEE IECON, Orlando, FL, Nov. 1995, pp. 546-551.

11. R. Caceres and I. Barbi, "A boost dc-ac converter: analysis, design and experimentation," IEEE Transactions on Power Electronic. America, vol. 14, January 1999, pp. 134-141.

12. P. Sanchis, A. Ursa, E Gubia and et al. "Boost dc-ac inverter: A new control strategy," IEEE Transactions on Power Electronics. America, vol. 20, March 2005, pp. 343-353.

13. D. Cortes, J. Alvarez and N. Vazquez, "Output feedback sliding- mode control for the boost inverter," IEEE Industrial Electronics, IECON 2006 - 32nd Annual Conference on, France, November 2006, pp 1890-1895.

\section{AUTHORS PROFILE}

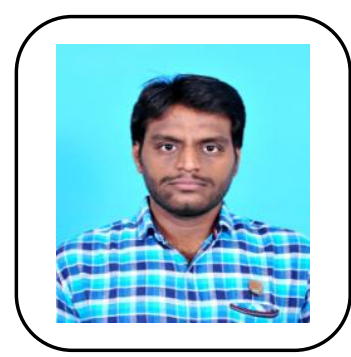

V S Prasadarao K received B. Tech and M. Tech degrees form JNTU Kakinada A. P in 2011 and 2014 respectively. Presently he is working as assistant professor in Shri Vishnu Engineering college for women, bhimavaram. His research areas are power converters, renewable energy systems, FACTS devices and electric drives.

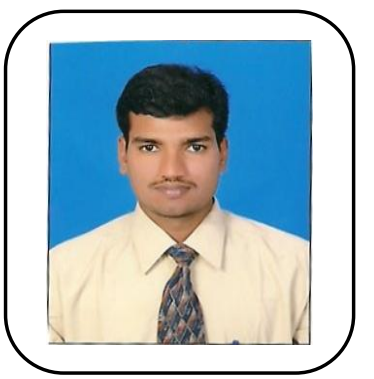

Nagalinga Chary Kodavatiganti received $M$. Tech degree form JNTU Kakinada A. P in 2011. Presently he is working as assistant professor Lakireddy Bali Reddy college of Engineering, My avaram, A. P. His research areas are renewable energy systems, FACTS devices and distributed generation systems.

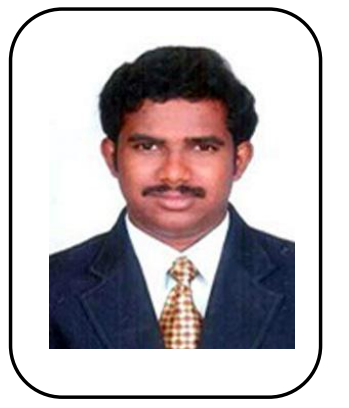

A V Ravi Kumar received M. Tech degree form JNTU Kakinada A. P in 2013. Presently he is working as assistant professor Lakireddy Bali Reddy college of Engineering, My avaram, A. P. His research areas are renewable energy systems, Smart Grid and distributed generation systems. 